\title{
Long-term variability of estuarine meiobenthos: an 11 year study*
}

\author{
Bruce C. Coull \\ Belle W. Baruch Institute for Marine Biology and Coastal Research, Marine Science Program, and Department of Biology, \\ University of South Carolina, Columbia, South Carolina 29208, USA
}

\begin{abstract}
Eleven years of monthly (or fortnightly) meiofauna abundance and physical variable data at 2 subtidal estuarine sites (sand and mud) in South Carolina, USA suggest that complex interactions control faunal abundance. At the mud site abundance peaked in late winter/early spring, reaching over 1800 meiofauna $10 \mathrm{~cm}^{-2}$; seasonal abundance was correlated with salinity changes. In sand, abundance peaked in mid-summer and was positively correlated with temperature (and negatively with RPD). Variability in abundance at the mud site was appriximately twice that of the sand site, and year to year variability was greater at both sites than the inherent seasonality. There were no long-term cycles in the fauna or temperature/salinity at either site; 12 mo was the period recurrent throughout the data set. The period 1975-1977 had the highest abundances at both sites, but these peaks were not correlated with any of the measured (or obtained) physical variables. Grain size at the sand site decreased in the 1980 's and there was a concommitant decrease in the abundance of copepods and in increase in the nematode/copepod ratio.
\end{abstract}

\section{INTRODUCTION}

The present study focuses on variation and the relations of meiobenthos abundance with environmental factors over 11 yr. Typically, marine benthic community studies are limited temporally and, except for McIntyre \& Murison (1973), previously published longterm' meiofauna results (all taxa) are those based on about a year's duration (e.g. Stripp 1969, Tietjen 1969, Coull 1970, de Bovée \& Soyer 1974). However, 7-yr population abundances of 3 harpacticoid copepods have been reported by Herman \& Heip (1983). Longterm data sets on any taxon in any habitat are rare, and practically non-existent (or unpublished) for the marine environment, yet such data sets have become increasingly recognized as important for understanding ecosystem functioning (Weins 1977, Callahan 1984). The present study was conducted within the confines of the North Inlet estuarine system, the only marine estuarine site in the National Science Foundation's LTER (Long Term Ecological Research) network. North Inlet (Fig. 1) is a natural, undisturbed ecosystem

\footnotetext{
- Contribution No. 575 from the Belle W. Baruch Institute for Marine Biology and Coastal Research
}

maintained for conservation and research. This study describes natural fluctuations of the meiobenthos at 2 sites; a similar data set including all meiobenthic taxa does not exist.

The original tenet of this research was to determine if natural meiobenthic assemblages exhibited continuity over time and to monitor several physical variables to determine if these influenced long-term temporal patterns. A long-term data set such as the one reported here is necessary to determine if natural populations fluctate; in addition it provides a data base for hypothesis testing (Coull 1985). Several experimental and in-depth analyses of the meiofauna at the 2 sites have already been published (Vernberg \& Coull 1974, 1975, 1981, Coull 1975, 1976, 1985, Coull \& Vernberg 1975, Coull \& Dudley 1976, Sellner 1976, Coull \& Fleeger 1977, Ivester \& Coull 1977, Coull \& Hogue 1978, Hogue 1978, Coull \& Bell 1979, Coull et al. 1979, Ivester 1980, Coull \& Grant 1981, Findlay 1981, 1982, Montagna et al. 1983, Coull \& Palmer 1984, Creed \& Coull 1984, Eskin \& Hopper 1985). They should be consulted for further information on the meiofauna of the 2 sites. The present paper provides a summary of major taxon data, discusses major longterm and seasonal trends and reports correlations with physical factors and between taxa. Copepod species 
analysis follows (Coull \& Dudley 1985) and nematode species analysis for 3 yr (1980-1982) is in preparation (Eskin unpubl.)

\section{METHODS AND MATERIALS}

Field and laboratory. The study sites (1 sand, 1 mud) in North Inlet, South Carolina, USA $\left(79^{\circ} 10^{\prime} \mathrm{W}\right.$, $35^{\circ} 20^{\prime} \mathrm{N}$ ), (Fig. 1) were sampled monthly from January 1973 through December 1980 and every 2 wk Jan 1981-Dec 1983. At each site 4 replicate core samples were taken up to March 1976, 3 replicates from Apr 1976-Dec 1980 and 2 replicates from Jan 1981-Dec 1983. All cores were taken to the depth of the redox potential discontinuity (RPD); typically 1 to $2 \mathrm{~cm}$ in mudi $_{4}$ to $10 \mathrm{~cm}$ in sand. Both sites are subtidal, located $1 \mathrm{~m}$ below MLW.

Each core sample was extruded and immediately fixed in $10 \%$ borax-buffered formalin with Rose Bengal. Salinity was measured by refractometer and Eh (Sep 72-Dec 76) by platinum electrode. Sediment samples were collected for organic analysis up to 1978, and for sediment size analysis monthly or quarterly (up to Sep 1979) and then monthly (Mar-Dec 1983). Oxidizable organic matter was determined using the wet dichromate method (Walkley \& Black 1934).
Granulometric parameters were measured by wet sieving through phi series sieves to $63 \mu \mathrm{m}$, and drying and weighing the sediment retained on the sieves. An aliquot of the material passing the $63 \mu \mathrm{m}$ sieve was removed for pipette analysis (Folk 1968). Sorting coefficient was calculated as $S_{0}=\sqrt{Q_{1} / Q_{3}}$ (Trask 1932).

Four data sets were collected to assess potential temperature effects: (1) surface-sediment temperature measurements taken at the time of meiofauna sample collection (Jan 73-Dec 83); (2) minimum and maximum daily air temperature recorded at the Georgetown County, SC, Airport, from Jan 35-Dec 78 (44 yr); (3) daily surface water temperatures from the mouth of the North Inlet estuary, Jun 79-Dec 83; (4) heating and cooling degree days data collected at the Charleston Airport, Charleston, SC, Dec 68-Apr 84.

Mud samples were extracted using Ludox centrifugation (de Jonge \& Bowmann 1977); the sand samples by the shaking-supernatant technique of Wieser (1960). All animals retained on a $63 \mu \mathrm{m}$ sieve were enumerated to major taxon; every copepod and every 4 th nematode was removed for species identification. Since all sorted samples were formalin fixed, softbodied taxa abundance (e.g. gastrotrichs, turbellarians, ciliates) was probably underestimated (Hulings \& Gray 1971). Ciliates may have been further underestimated since the samples were collected on a $63 \mu \mathrm{m}$

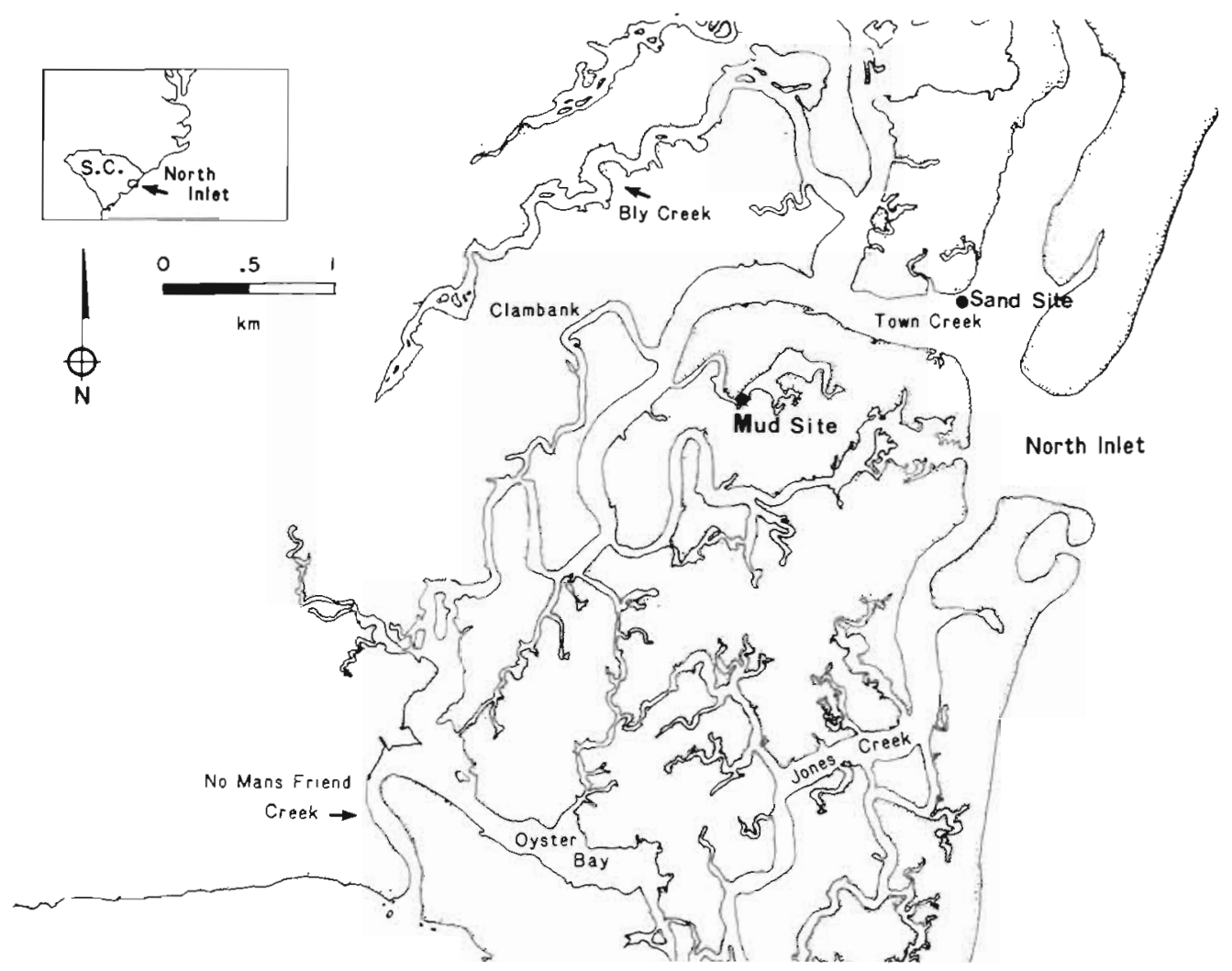

Fig. 1. Map of North Inlet, South Carolina (USA), region noting the location of the 2 long-term sites 
sieve; thus only the larger ciliates (e.g. Tracheloraphis spp.) were retained.

Data analysis. All data have been stored on the University of South Carolina's Amdahl 16-11 and IBM 3081 computers as SAS (SAS Institute 1982) data sets. All statistical tests have been conducted using SAS software. Even though our variances around taxon abundances were not homoscedastic (Fmax test, Sokal \& Rohlf 1981), we decided that transformation was not necessary because Scheffé (1959, p. 353) indicated that during ANOVA little difference would occur in the resulting F-value with sample sizes as large as those presented here. To test Scheffé's prediction I transformed the data $[\log (x+0.001)]$ and conducted the same analysis on the transformed and untransformed data. The results were virtually identical (2 slight changes in p values; neither changed significance) and therefore I present the results based on the untransformed data.

Scheffé's multiple comparisons (experiment-wise error rate $=E W E R, P<0.05$ ), was used a posteriori if ANOVA indicated a significant difference between treatments. Pearson product means and correlation coefficients (r) are used throughout.

Following the outline of Fry et al. (1981 p. 202) spectral analysis was used to identify periodicities in taxon abundance or a physical variable. Spectral density estimates (variance) were obtained using finite Fast Fourier Transformations (FFT). This procedure fitted sine and cosine waves of different amplitudes on detrended (i.e. after any increasing trend was removed by utilizing the residuals of a linear regression) monthly data (in 1981-1983 only alternate fortnightly samples were used). The Kolmogorov-Smimov Statistic (Box \& Jenkins 1970) was performed to test for 'white noise', (i.e. a series of independent and identically distributed normal random variables: Fry et al. 1981). White noise was not present in any of the parameters tested.

I chose FFT spectral analysis instead of the Maximum Entropy Method (MESA), used in the only other time series analysis of meiofauna (Herman \& Heip 1983), because: (1) in MESA there is no accepted method to generate confidence intervals that will statistically differentiate peaks from background noise (Kirk et al. 1979) but there is in FFT (Fry et al. 1981); (2) both methods produce similar results with long ( $>100$ points) data sets (Kirk et al. 1979, p. 59); (3) FFT is the most widely used, available and accepted time series analysis for biological data (Box \& Jenkins 1970, Platt \& Denman 1975, Fry et al. 1981). Herman \& Heip (1983) state that MESA can resolve cycles equal to the data set length, but I can find no such verification in Kirk et al. (1979), except for the statement that MESA 'can predict (my emphasis) periods longer than the length of the available data' (p. 72). Intuitively, no time series method can resolve periods greater than $1 / 2$ the wave length because the 'period' must be repeated to determine if it is indeed a true period. If it is not repeated one is dealing with trend analysis and reported cycles beyond $1 / 2$ the data set length must be viewed with caution.

\section{RESULTS}

\section{Physical factors}

The 2 sets of water temperature data, monthly sediment interface for $11 \mathrm{yr}$ and daily surface water temperature for $4 \frac{1}{2} \mathrm{yr}$, for times when both were collected, are highly correlated $(\mathrm{r}=0.9676$; $\mathrm{P}<0.0001)$, indicating that although sediment/water interface temperature was measured only monthly or biweekly, it tracks the overall temperature trend. Time series analysis on the 11 -yr monthly water temperature data, the 44-yr air temperature data and the 14-yr degree day data indicate only 1 period; $12 \mathrm{mo}$, the seasonal cycle. There are no longer term temperature cycles in these 3 data sets.

Sediment/water interface temperature ranged from $4.8^{\circ} \mathrm{C}$ in January 1978 to $31^{\circ} \mathrm{C}$ in August 1978 and 79. The mean annual temperature cycle ranged from $10 \pm 0.6^{\circ} \mathrm{C}$ (Jan) to $29 \pm 0.5^{\circ} \mathrm{C}$ (Aug). In all 3 data sets covering the study period (monthly water measurements, daily air temperatures, degree days) January 1978 was the coldest month. There were no significant differences in water temperature among years (oneway ANOVA, $\mathrm{df}=10 ; \mathrm{F}=1.37, \mathrm{P}=0.30$ for mud; $\mathrm{df}=10, \mathrm{~F}=1.07, \mathrm{P}=0.99$ for sand)

Salinity measured at the time of meiofauna sample collection fluctuated seasonally (Fig. 2) and was slightly lower at the mud (Bread and Butter Creek) site

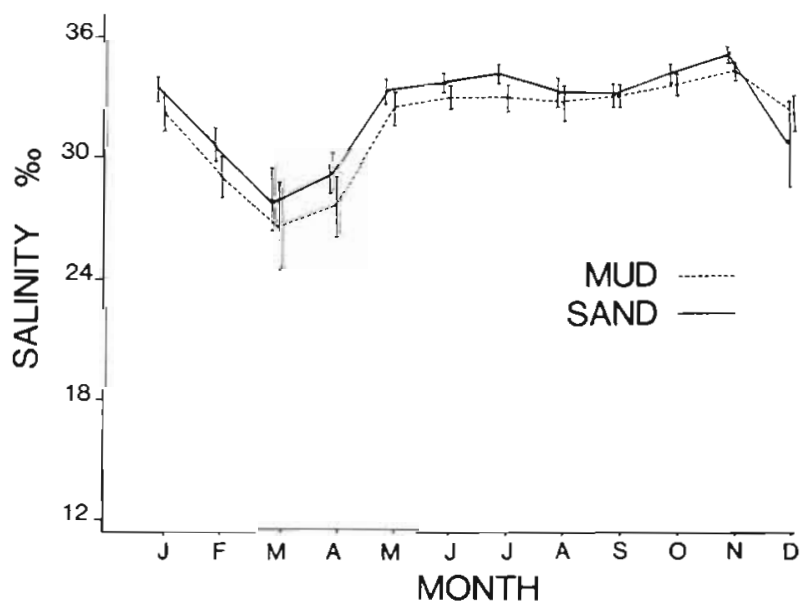

Fig. 2. Mean ( $\pm \mathrm{SE}$ ) monthly salinity at the 2 sites. Means of $11 \mathrm{yI}$ 
because it is further from the Inlet mouth than the sand site (Fig. 1). Lower salinities in late winter/early spring (Fig. 2) are the results of typically heavy spring rains in South Carolina. Forty-four yr of daily precipitation data from the Georgetown airport confirm that precipitation is heaviest during the late winter/early spring. While correlation coefficients between precipitation and salinity indicate that they are negatively correlated; the correlations are not significant $(P=0.40$ at both sites). This lack of significance is understandable considering that our salinity was measured once or twice a month and rainfall was taken daily. Salinities are not significantly different among years (one-way ANOVA, $\mathrm{df}=10 ; \mathrm{F}=1.34 ; \mathrm{P}=0.23$ ).

The redox potential discontinuity (RPD) ranged from 0 to $3 \mathrm{~cm}$ deep at the mud site; 2 to $11 \mathrm{~cm}$ at the sand site. Seasonally it fluctuated, being closest to the surface in the summer, and deeper in winter (see Montagna et a1. 1983, their Fig. 1 \& 2). Depth of the RPD was negatively correlated with temperature at both sites $(r=-0.44, \quad P \leqq 0.0001$ in mud; $r=-0.26$, $\mathrm{P}=0.0007$ in sand). The RPD measurements are not presented in the correlation analysis with taxa since RPD is redundant (negatively) with the seasonal temp- erature pattern. Oxidizable organic matter ranged from 1.32 to $6.10 \%$ at the mud site; and 0.02 to $1.02 \%$ at the sand site. There was no seasonal pattern to the organic measurements.

Sediment granulometric parameters were constant at both sites from January 1973 to September 1979. At the mud site median grain size (mgs) ranged from 29 to $63 \mu \mathrm{m}$; sorting coefficient (S) from 0.95 to 2.50 $(\overline{\mathrm{x}}=1.46)$; and percent silt-clay ( $\% \mathrm{SC}$ ) from 59 to $69 \%$. At the sand site mgs ranged from 188 to $425 \mu \mathrm{m}$ $(\overline{\mathrm{x}}=278.9 \mu \mathrm{m})$, with only 4 measurements $(\mathrm{n}=57)$ below $200 \mu \mathrm{m}$; $\mathrm{S}$ from 0.92 to 1.73 with only 2 measurements below 1.20 ; and \% SC from 0.6 to $11.3 \%$. Since there were no differences in 7 years of sampling, we discontinued granulometric analysis in October 1979. However, some faunal changes and gross topographic changes at the sand site by early 1983 suggested that the sediment was changing at that site. Therefore, in April 1983 biweekly granulometric analysis were reinitiated at both sites. The 1972 to 1979 mud site values were not significantly different from the 1983 values. At the sand site in 1983, mgs ranged from 173 to $197(\overline{\mathrm{x}}=186.3 ; 92.5 \mu \mathrm{m}$ smaller than $1972-79)$ and $\mathrm{S}$ ranged from 1.20 to $1.40(\overline{\mathrm{x}}=1.24)$, significantly diffe-

Table 1. Eleven yr (Jan 1973 - Dec 1983) mean meiofauna abundance at the 2 study sites (see Table 4 for abundances by year)

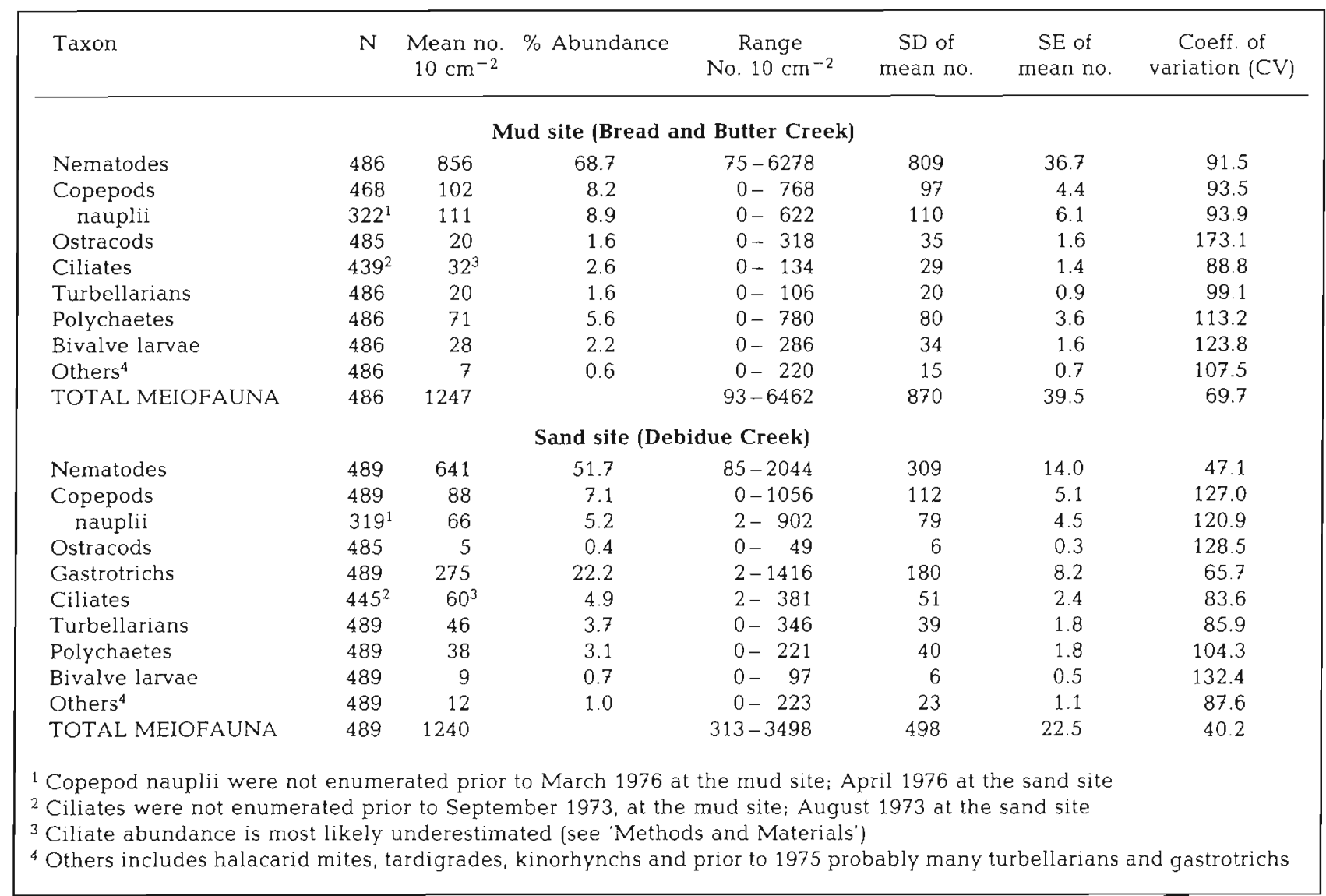




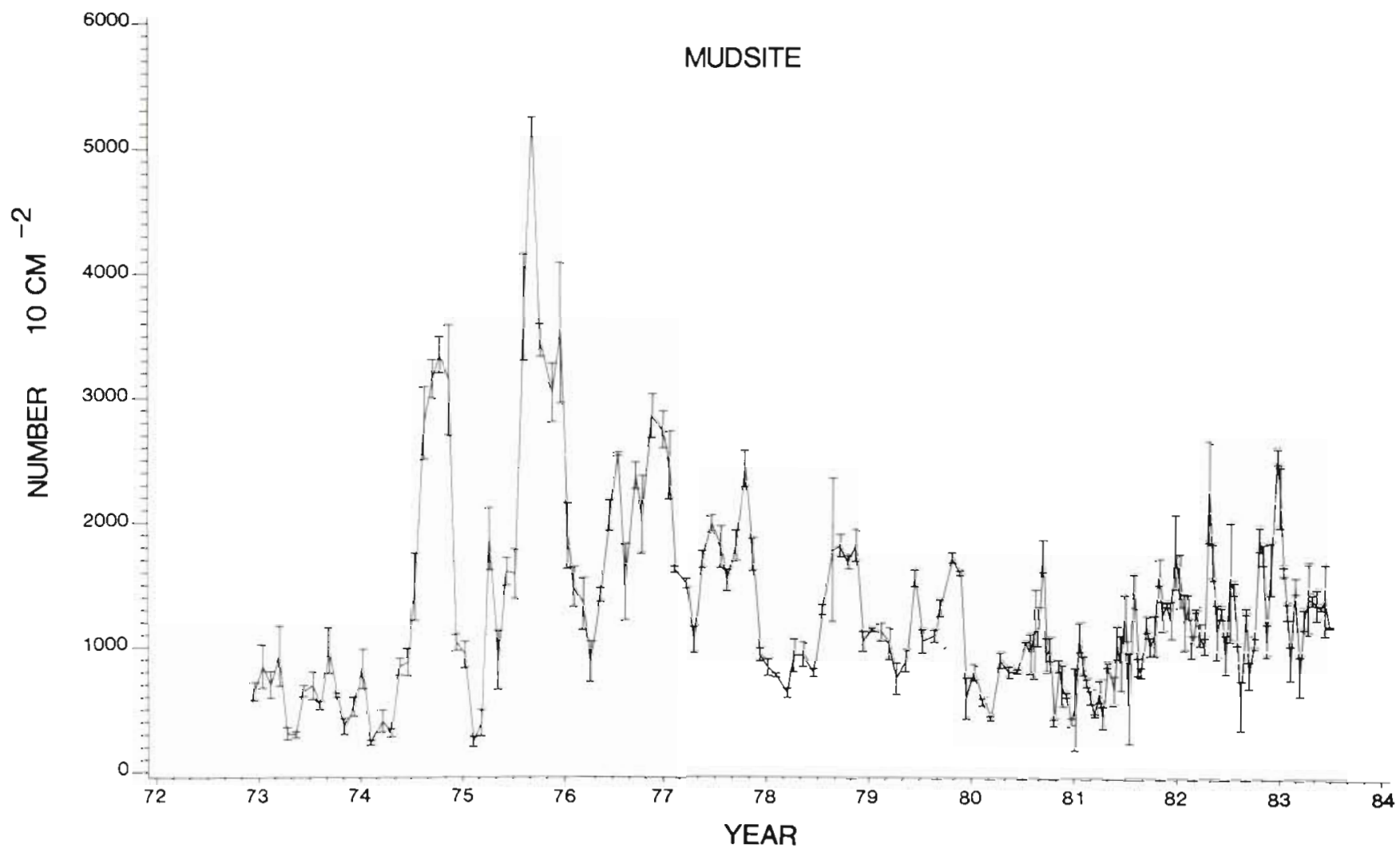

rig. 3. Mean abundance ( \pm SE) of total meiofauna for each sampling time at the mud site (Jan 1973-Dec 1983). Year labels, e.g. $73,74,75$, are placed at yearly midpoints (1 Jul)

rent from the 1972-79 measurements (ANOVA; mgs, $\mathrm{DF}=1, \quad \mathrm{~F}=11.94 ; \mathrm{P}=0.001 ; \quad \mathrm{S}, \mathrm{DF}=1, \quad \mathrm{~F}=15.49$, $\mathrm{P}=0.0002)$.

\section{Fauna}

The 11-yr mean abundance and some summary statistics for the meiofauna at the 2 sites are listed in Table 1. Nematodes were the most abundant taxon, copepods (including nauplii) were 2 nd at the mud site and 3 rd at the sand site. Gastrotrichs were 2nd in abundance $(22.2 \%)$ at the sand site. Table 1 also provides estimates of variance (i.e. $\mathrm{SD}, \mathrm{SE}, \mathrm{CV}$ ) and even though the mean meiofaunal abundance at the 2 sites was remarkably similar over the $11 \mathrm{yr}$ (e.g. total meiofauna $=1247$ [mud]; 1240 [sand] $10 \mathrm{~cm}^{-2}$ ) variance at the mud site was approximately twice that at the sand site (Fig. $3 \& 4$ ). Most of the variance associated with the mud site was due to year-to-year fluctuations in abundance, particularly 1975-77. At the mud site two-thirds of the summed variance for the $11 \mathrm{yr}$ occured in 1975-76 (Table 2) whereas at the sand site the variance among years was much more constant (Table 2). The amplitude of the seasonal abundance fluctuations was also greater at the mud site compared to the sand site. The sand site monthly total meiobenthic abundances ranged from $954 \pm 503$ (SD) in January to $1490 \pm 499$ in September ( $\bar{x}$ range $=536)$, whereas the mud site mean monthly abundances (total meiofauna) ranged from $862 \pm 472$ in August to $1841 \pm 1967$ in March ( $\bar{x}$ range $=979$ )

Table 2. Summary of variance component analysis comparing amount of the summed 11 yr variance attributable to any 1 yr for total meiofauna

\begin{tabular}{|c|c|c|}
\hline \multirow[b]{2}{*}{ Year } & \multicolumn{2}{|c|}{$\%$ Variance due to $1 \mathrm{yr}$} \\
\hline & Mud site & Sand site \\
\hline 1973 & 1.5 & 9.1 \\
\hline 1974 & 1.6 & 6.3 \\
\hline 1975 & 24.6 & 8.2 \\
\hline 1976 & 42.3 & 11.4 \\
\hline 1977 & 6.7 & 15.4 \\
\hline 1978 & 6.3 & 8.8 \\
\hline 1979 & 4.1 & 9.9 \\
\hline 1980 & 3.2 & 6.2 \\
\hline 1981 & 2.3 & 4.7 \\
\hline 1982 & 3.4 & 13.8 \\
\hline 1983 & 4.0 & 6.2 \\
\hline
\end{tabular}




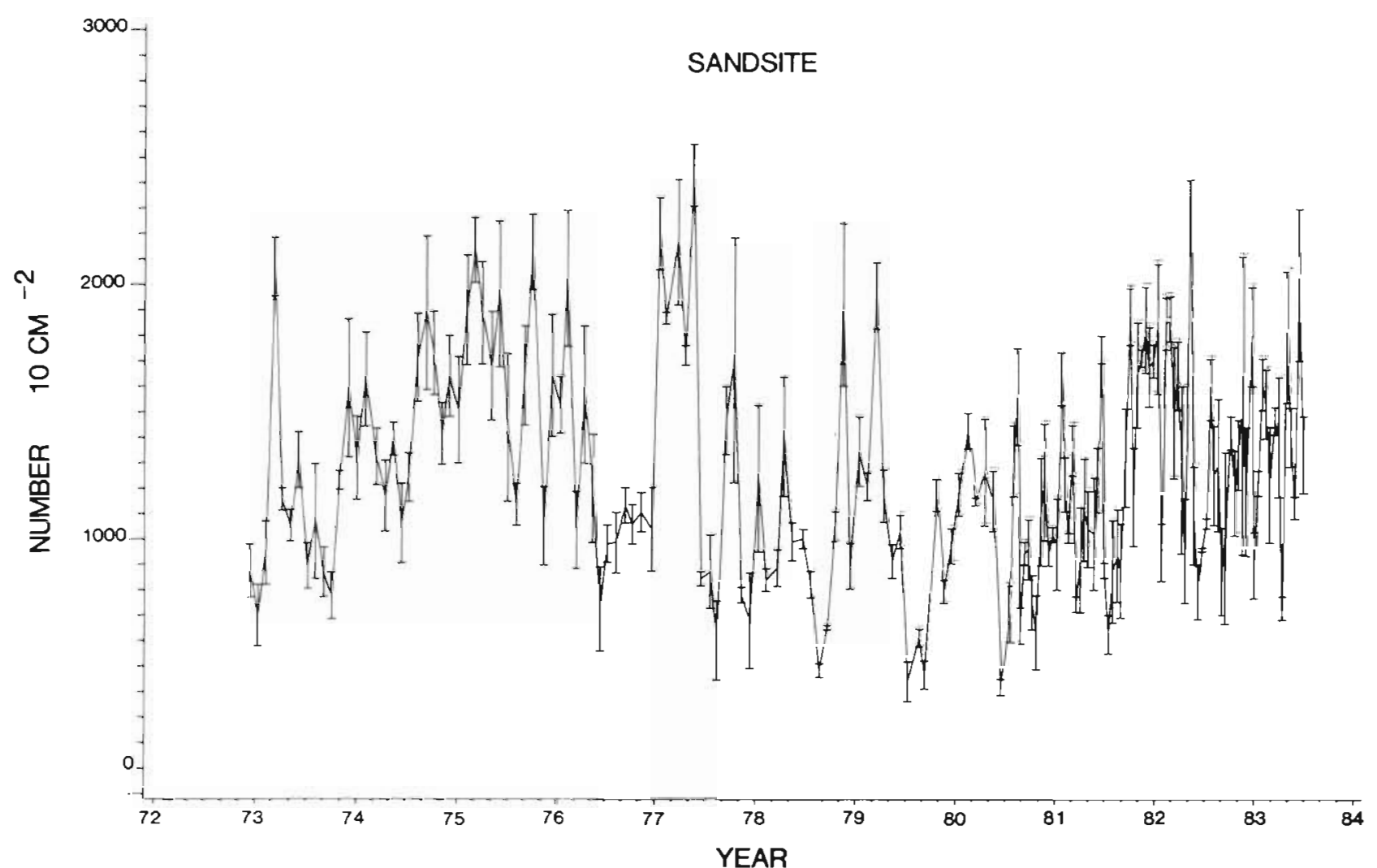

Fig. 4. Mean abundance $( \pm S E$ ) of total meiofauna for each sampling time at the sand site (Jan 1973-Dec 1983). Year labels, e.g. $73,74,75$, are placed at yearly midpoints $(1 \mathrm{Jul})$

Fig. 3 and 4, while providing the mean \pm SE point for each sampling date (note that the points become closer in 1981 when fortnightly sampling was initiated), mask both seasonal and yearly patterns. There- fore, the monthly means (i.e. the means of 11 January's, 11 February's etc.) and the yearly means (i.e. mean for 1973, for 1974, etc.) have been plotted in Fig. 5, 6 and 7 . to more clearly illustrate the seasonal and 11 -yr trends.

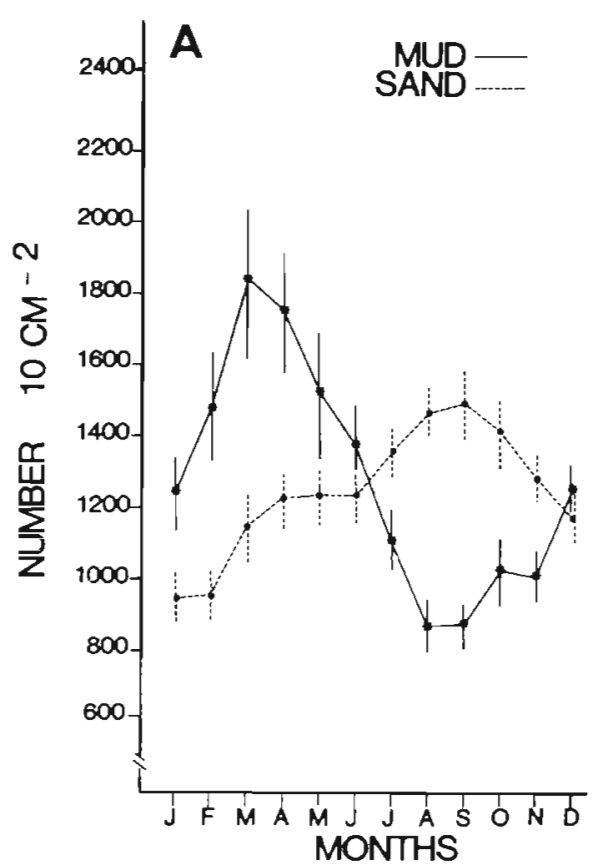

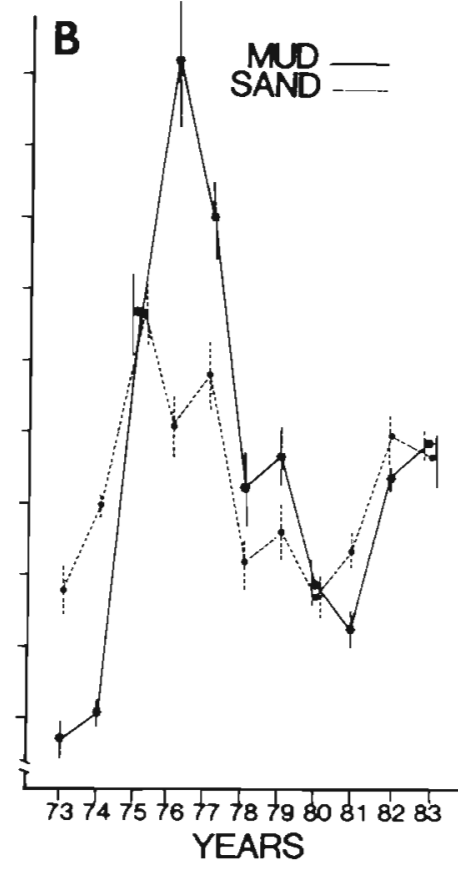

Fig. 5. (A) Monthly mean abundance $( \pm \mathrm{SE})$ of total meiofauna (i.e. all 11 January's, etc.) at mud and sand sites. (B) Yearly mean abundance ( $\pm \mathrm{SE}$ ) of total meiofauna at the mud and sand sites 

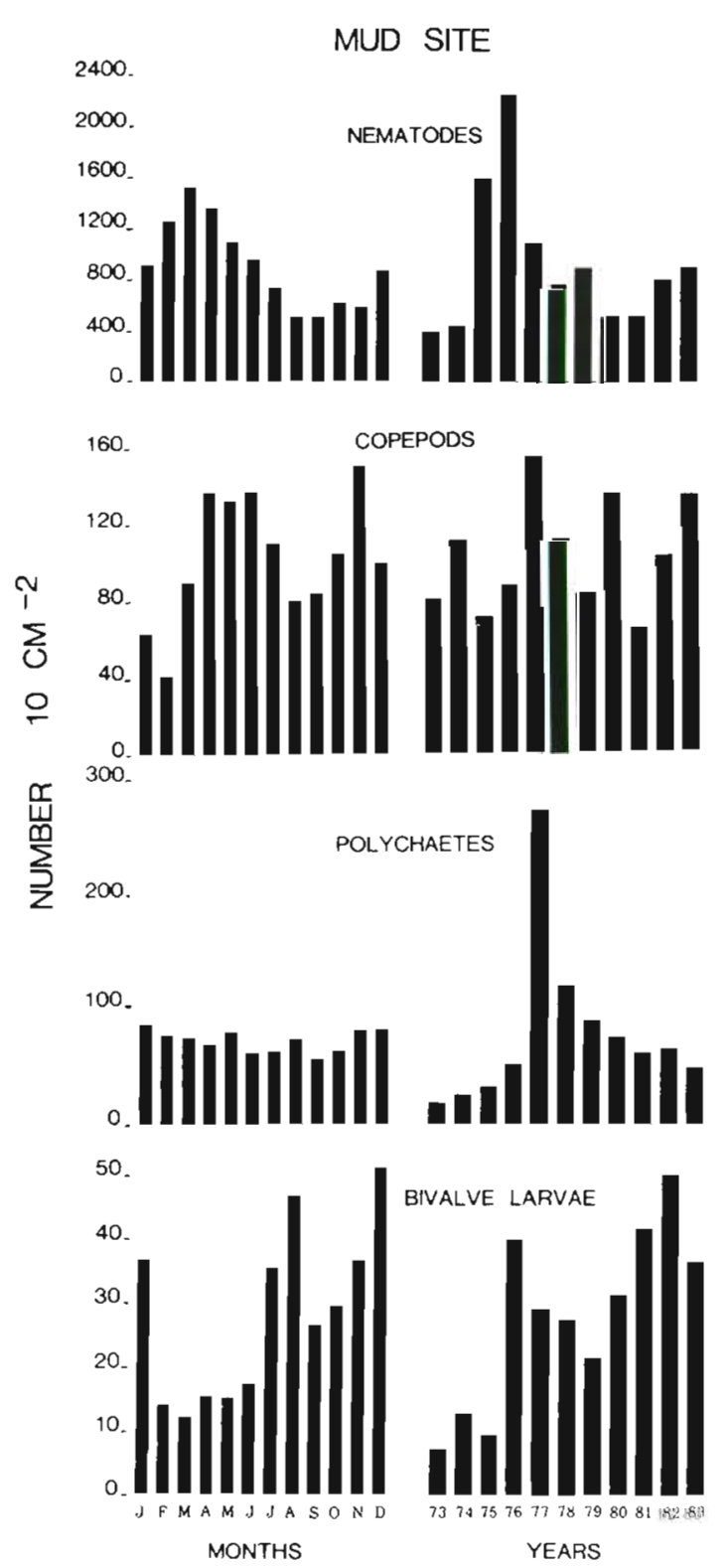

Fig. 6. Histograms of mean monthly and yearly abundances $( \pm \mathrm{SE}$ ) of 4 taxa (nematodes, copepods, polychaetes, bivalve larvae) at mud site

At the mud site, maximum abundance generally occurs in the spring (Fig. 5A \& 6), whereas sand site maximum abundance typically occurs in the late summer (Fig. 5A \& 7). Correlation coefficients for all major taxa with temperature and salinity at both sites (Table 3 ) illustrate that the dominant taxa were negatively correlated with salinity at the mud site and positively correlated with temperature at the sand site. There was no consistent correlation pattern of the lesser abundant taxa with temperature and salinity (Table 3 ).

One-way analysis of variance considering temperature or salinity with abundance of total meiofauna, nematodes, or copepods, yielded results similar to
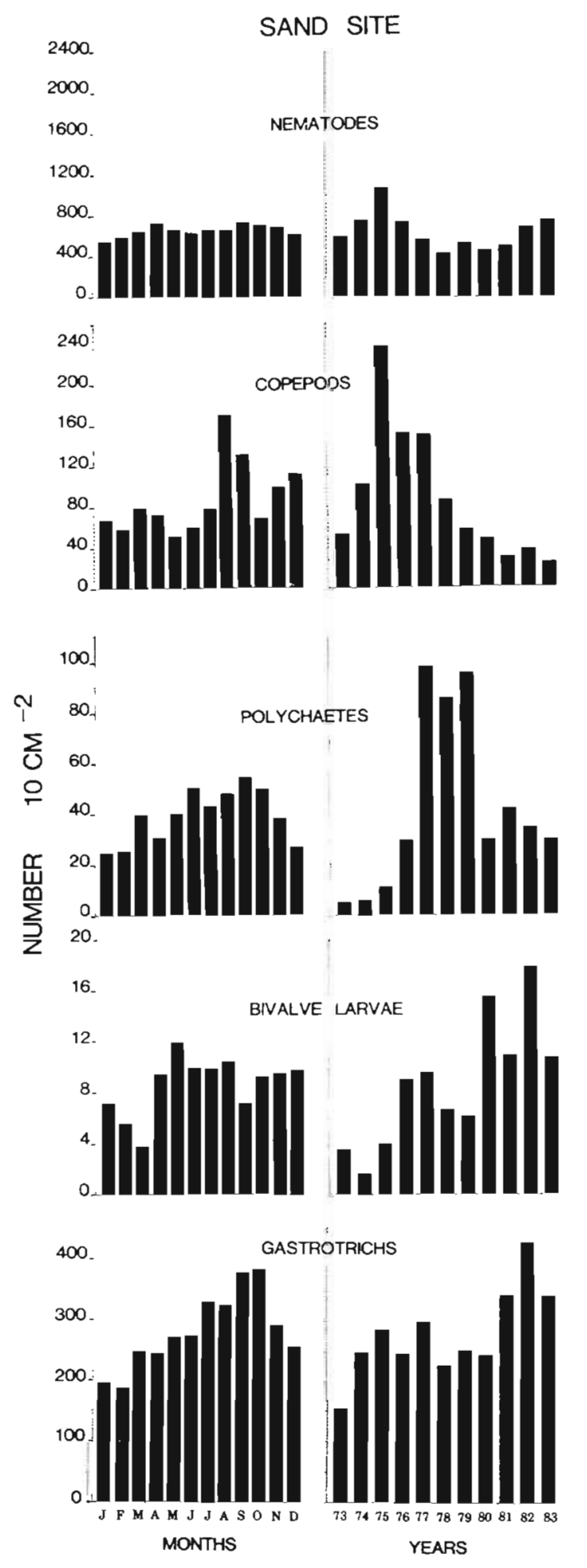

Fig. 7. Histograms of mean monthly and yearly abundances $( \pm \mathrm{SE}$ ) of 5 taxa (nematodes, copepods, polychaetes, bivalve larvae, gastrotrichs) at sand site

those of the correlation analysis (Fig. $8 \mathrm{~A}, \mathrm{~B}$ ). Although the models are significant $(P \leqq 0.0001), r^{2}$ 's are low because of so many error degrees of freedom (466). The 
runs test, $\mathrm{p}=0.01$ ) and bivalve larvae, with extremely low abundances at the sand site (Table $1 \& 4$ ), did not peak in abundance in 1975-77.

Time series (spectral) analysis indicates 1 peak in faunal abundance at a frequency of 12 mo for all taxa (except copepods) at both sites. Copepods at the mud site have peaks at periods of 6 and 12 mo, suggesting 2

Table 5. F values from ANOVA's for each taxon comparing months, years and months nested within years. The months ANOVA compared all Januarys to all Februarys to all Marches, etc.; the year ANOVA compared 1973 to 1974 to 1975 etc., and the nested ANOVA compared January 1973 to January 1974 to January 1975, and February 1973 to February 1974 to February 1975, etc. All treatments for all taxa, i.e. monthly, year, month (year) are significant ( $\mathrm{P} \leqq 0.0001)$

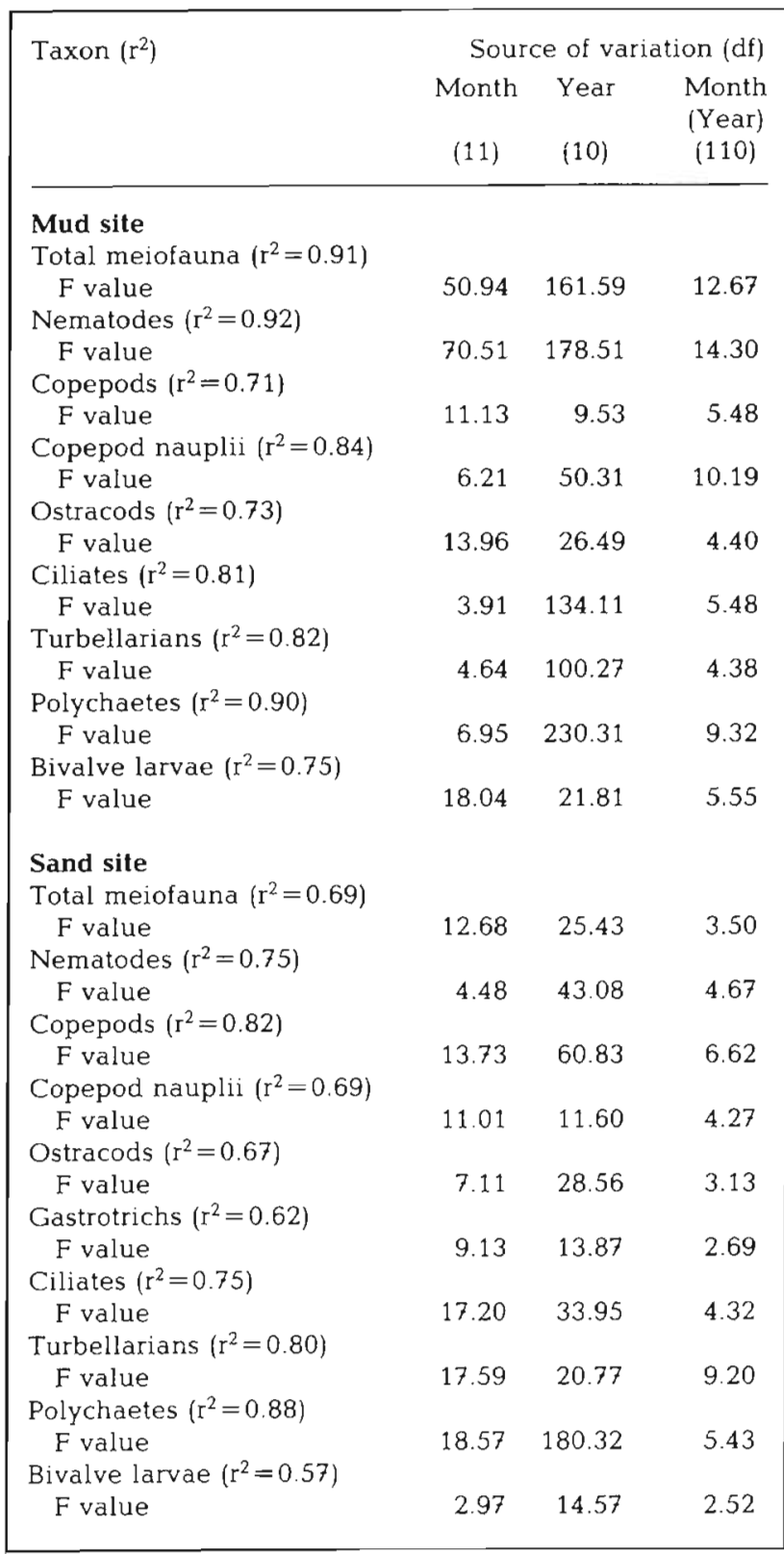

major abundance periods per year. Most taxa (except and copepods) also show a periodicity at $11 \mathrm{yr}$ (the data set length), suggesting no further periodicity with the data set. No other abundance cycles were detected. (Note: FFT time series analysis [as explained in 'Methods and Materials'] can only determine periodicities at $\leqq 1 / 2$ the total record length [Platt \& Denman 1975]. Since my data set is $11 \mathrm{yr}$, the maximum periodicity I could determine was $5.5 \mathrm{yr}$.)

Table 5 lists the $F$ values for all taxa from ANOVAs to test for differences between months (i.e. all Januarys to all Februarys, etc.), between years, and between the same month in different years (i.e. nested model; January 1973 compared to January 1974, etc.). Most of the variance for a taxon comes from between-year differences (Table 5, Column 2). In only 1 case (copepods at the mud site) is the F value for months larger than that for years. Since there are significant differences between years (Table 2; Table 4 Scheffé comparisons) and seasonality (Fig. 3, 4, 5A \& 6) accounts for the between month variations, year to year changes contribute more to the total within taxon variance than does the inherent seasonality (Fig. $5 \& 6$; Table 5).

Yearly means and the ratio of nematodes to copepods (N/C) for each sampling date have been included (Fig. 9) because the N/C ratio has been the subject of considerable debate in meiobenthic ecology (Coull et al. 1981, Raffaelli 1981, Raffaelli \& Mason 1981, Warwick 1981, Amjad \& Gray 1983). The ratio at both sites was typically below 50 and there was no significant change in the ratio over time at the mud site (Fig. 9). At the sand site the ratio increased starting in 1979 (Fig. 9) when the sand site sediment became finer. There was no seasonality to the ratio at either site.

\section{DISCUSSION}

The abundance values reported here (total meiofauna, $\overline{\mathrm{x}}=124710 \mathrm{~cm}^{-2}$ in sand, 1240 in mud) are well within the range known from similar sediments world-wide (McIntyre 1969, Tietjen 1969, Coull 1973, Coull \& Bell 1979), but mean total meiofauna or any individual taxon abundance (Tables 1 \& 4) is not the primary point of this paper; temporal variability is!

Rarely is a data set of the magnitude, frequency, and replicability of the present one available. When one is, repeatable cycles are a priori expected. While there were repeatable annual cycles for the dominant, and most of the other, taxa in the present data set (Fig. 3, 4 , $5 \mathrm{~A}, 6 \& 7$ ), there were no long-term ( $>1$ yr but $<5.5$ yr) repeatable cycles. The total meiofauna seasonal cycles (Fig. 5A), were correlated (Table 3; Fig. 8) with salinity (mud) and temperature (sand) and in a rather straightforward manner. The mud late-spring decrease is also 


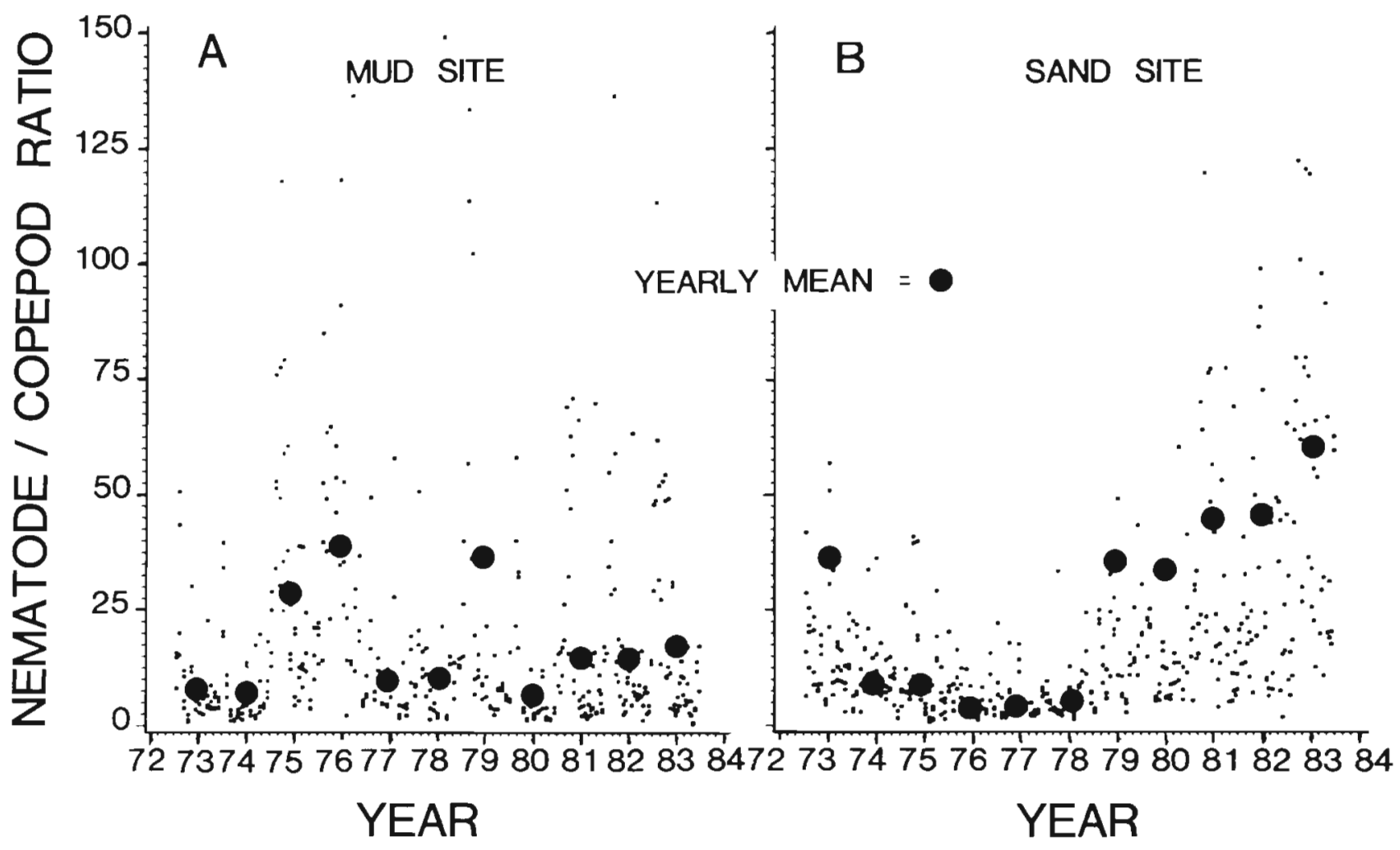

Fig. 9. (A) Scatter plot of nematode/copepod (N/C) ratio (every replicate; $n=486$ ) with yearly mean $N / C$ ratio overlain at mud site. (B) Scatter plot of nematode/copepod (N/C) ratio (every replicate; $n=486$ ) with yearly mean N/C ratio overlain at sand site

the time of influx of various meiofauna predators into the system (Coull \& Palmer 1984). Unfortunately, there are no 11 -yr estimates of predator abundances in North Inlet, but for the 1981-83 period a major meiofaunal predator, a juvenile fish (Leiostomus xanthurus; common name $=$ spot) entered the system regularly in March (D. M. Allen pers. comm.). Guts of 20 to $50 \mathrm{~mm}$ L. xanthurus are regularly packed with meiofauna (Sheridan 1979, Chestnut 1983) and are the major subject of ongoing predation experiments with meiofauna.

The decrease in meiobenthos at the mud site, correlated with the increasing salinity (Fig. 2) and coincident with the juvenile spot influx, suggests that the mechanisms regulating meiofaunal seasonal patterns in mud are complex, interactive and not easily discernible. One possibility is that decreasing salinity (at winter temperatures) triggers the development of some preferred meiofaunal food source in the mud which leads to concomitant meiofaunal increases, and subsequent spot growth. By March meiofauna reach maximium abundance (Fig. 5A) and the fish are of the size $(\sim 20 \mathrm{~mm})$ to eat meiofauna. The fish eat the meiofauna and by summer have grown to a size where meiobenthos are not the preferred prey. The mud meiofauna then start slowly increasing in abundance (Fig. 5A) to reach maximum abundances in late winter/early spring. While this scenario is speculative, based on correlations and juvenile spot catches, it serves as an example of possible cause-effect lineages. Such correlation analysis cannot explain a cause but it can suggest research avenues to be experimentally tested.

The copepods at the mud site demonstrate 2 seasonal peaks (Fig. 6; results of time series analysis); from April to June and in November. These peaks are due to different species (Coull \& Vernberg 1975, Coull \& Dudley 1985) reaching maximum abundance at different times. See Coull \& Dudley (1985) for analyses of copepod species patterns over the 11 -yr period.

The sand site is a hydrodynamically active site (Grant 1981, Montagna et al. 1983) and this physical activity apparently so dominates the habitat that total meiofaunal abundance is maintained at a relatively constant level within years, and even over the 11-yr. The mud site is much less hydrodynamically active and meiofauna abundance is much more variable seasonally and yearly. Fluctuations here, while partly related to salinity changes, may be regulated by other factors not measured in the present study. Bacteria and diatom abundance (measured for 1 yr only by Montagna et al. 1983) is an order of magnitude greater at the mud site, and predation on meiofauna is also known to be greater in muds than in sands (Coull \& Bell 1979). Thus, in sites where non-physical factors 
dominate, the amplitude of abundance fluctuations is greater. Biological controls then are suspected of causing the large fluctuations in meiofaunal abundance at the mud site, whereas the sand site abundances (lower variance) are much more homogenous and constant over the short (month-to-month) and long (year-toyear) terms. Certainly, a catastrophic physical event could change the fauna at either site drastically.

During the mid 1970's abundance peaked at both sites, but particularly at the mud site, and the reasons for these are unclear. These peaks were not correlated with any of the variables measured and were not part of $\mathrm{a} \leqq 5.5$ yr trend. One can speculate that the correct forcing function(s) were not measured and the peaks were indeed correlated with something. Perhaps the 1975-77 peak is part of a regular longer term cycle and with only 11 yr of data the cycle cannot be delineated (see Gray \& Christie 1983 for discussion of longer-term benthic cycles). There are probably many other potential explanations.

Although the 1975-77 abundance peaks in the North Inlet data cannot be readily explained, the declining copepod abundance at the sand site (Fig. 7), appears to be closely related to changing granulometry. Median grain size decreased significantly and sorting coefficients increased significantly. Interstitial copepods (those that require adequate spaces between sand grains to maneuver) have essentially been excluded from the sand site in the last few years (Coull 1985; Fig. 4), whereas there has been no change in the sediment surface dwelling epibenthic forms. This site appears to be undergoing a transition from a fine sand to a muddy sand; a transition that favors increasing gastrotrich abundance (Fig. 7).

The nematode/copepod ratio at the sand site increased in 1980-83 as the sediment size became finer. This increase is due to the decreased copepod abundances (Fig. 7) and is in agreement with the original Raffaelli \& Mason (1981) hypothesis that finer sediments should have a higher ratio. At the mud site, however, with its significantly lower median grain size ( 29 to $63 \mu \mathrm{m}$ mgs mud site; 173 to $425 \mu \mathrm{m}$ mgs sand site), the ratio is no different from the sand site (Fig. 9). Thus even with $11 \mathrm{yr}$ of monthly and fortnighty data, the $\mathrm{N} / \mathrm{C}$ ratio remains ambiguous as a measure of sediment 'quality'. Obviously a variety of factors control this ratio and it should be used with extreme caution as an indicator of environmental change.

The meiofaunal assemblages studied were cyclical with distinct repeatable seasonal periodicities. However, the order of magnitude of the seasonal and yearto-year abundances were not regular. The mid-1970's abundance maxima, while having the same seasonal cycle as other years, do not appear to be part of a longer term trend (at least not discernible from the data set length); but demonstrate the great inherent, unexplainable variability in natural meiofauna abundance. Without a long-term data set it would be impossible to document such major abundance fluctuations. The question arises, is $11 \mathrm{yr}$ enough? The answer is, obviously, that it depends on what is being asked. The seasonal patterns certainly could have been delineated with 3 to 5 yr of data (one must replicate years to validate the trends observed in a short data set), but even with $11 \mathrm{yr}$, no long-term trend (if, indeed, one exists) can be determined. Thus, if long-term cycles are of interest then 11 yr was not sufficient.

McIntyre \& Murison (1973), reporting on 10 yr of meiofauna data (monthly sampling for $12 \mathrm{mo}$; irregularly for 9 yr) on a Scottish sandy beach, have suggested that annual variations in meiofaunal abundance were quite small and that the total assemblages was relatively constant over the study period. Their sampling program was limited and perhaps not sufficient to record changes, and their results are in direct contrast to those recorded here. While the North Inlet sand site abundances were much less variable than the mud site abundance (Table 1), both sites had more year-to-year variability (Table 5) than seasonal variability. Although McIntyre \& Murison's conclusion may be correct for the intertidal sandy meiofauna of Firemore Bay, Scotland, it most certainly is not for the subtidal meiofauna of either a sandy or muddy site in a southeastern United States salt marsh estuarine complex.

Natural meiofaunal assemblages are complex, governed by a variety of factors (some, or many, of which are not or cannot be measured) and display large temporal variation. Continued monitoring however, will not provide answers to the interactive mechanisms controlling this complexity. Experiments based on the leads provided by the correlation/statistical analysis must be designed specifically for this purpose.

Acknowledgements. Especially, I thank Bettye W. Dudley who has sorted $>90 \%$ of the samples reported herein. Other sorters have included John W. Fleeger, Richard V. Levy, Brian M. Marcotte, and Jean P. Sikora; Richard A. Eskin, Donald G. Edwars, and Pamela Spurrier have greatly assisted with data analysis; Roberta McCutchen with sample collection; Richard Eskin and Bettye Dudley with graphics and Susan S. Bell, Elizabeth Blood, Richard A. Eskin, Robert J. Feller, Roberta L. Marinelli, Stephen E. Stancyk, John H. Tietjen and Richard $M$. Warwick have provided constructive criticisms on earlier drafts on this manuscript; all are gratefully acknowledged. This research was supported by the Biological Oceanography Section of the National Science Foundation through grants DES 7201573, OCE 7617584, OCE 7809450, OCE 8007968 and OCE 838114 (B. C. Coull, principal investigator) and the LTER Program of the Ecosystems section of NSF, Grant DEB 8012165 (F J. Vernberg, principal investigator). 


\section{LITERATURE CITED}

Amjad, S., Gray, J. S. (1983). Use of the nematode-copepod ratio as an index of organic pollution. Mar. Pollut. Bull. 14: 178-181

de Bovée, F., Soyer, J. (1974). Cycle annuel quantitative du méiobenthos des vases terrigènes côtières. Distribution verticale. Vie Milieu 24: 141-157

Box, G. E. P., Jenkins, G. M. (1980). Time series analysis, forecasting and control. Holden-Day, San Francisco

Callahan, J. T. (1984). Long-term ecological research. Bioscience $34: 363-367$

Chestnut, D. E. (1983). Feeding habits of juvenile spot Leiostomus xanthurus (Lacépède) in North Inlet Estuary, Georgetown, SC. M.S. thesis, University of South Carolina, Columbia

Coull, B. C. (1970). Shallow water meiobenthos of the Bermuda platform. Oecologia (Berl.) 4: 325-357

Coull, B. C. (1973). Estuarine meiofauna: A review: trophic relationships and microbial interactions. In: Stevenson, $L$. H., Colwell, R. R. (ed.) Estuarine microbial ecology. University of South Carolina Press, Columbia, South Carolina, p. $499-511$

Coull, B. C. (1975). Three new harpacticoid copepods from the North Inlet Estuary, South Carolina. Crustaceana 29: $113-126$

Coull, B. C. (1976). On the two laophontid harpacticoid copepods described by Wilson as Laophonte capillata, with keys to the genus Paronychocamptus. Trans. Am. microsc. Soc. 95: 35-4.5

Coull, B. C. (1985). The use of long-term biological data to generate testable hypotheses. Estuaries 8: 84-92

Coull, B. C., Bell, S. S. (1979). Perspectives of marine meiofaunal ecology. In: Livingston, R. J. (ed.) Ecological processes in coastal and marine ecosystems. Plenum Publ. Co., New York, p. 189-216

Coull, B. C, Dudley, B. W. (1976). Delayed naupliar development of meiobenthic copepods. Biol. Bull. mar. biol. Lab., Woods Hole 150: 38-46

Coull, B. C., Dudley, B. W. (1985). Dynamics of meiobenthic copepod populations: a long-term study (1973-1983). Mar. Ecol. Prog. Ser. 24: 219-229

Coull, B. C., Fleeger, J. W. (1977). Long-term temporal variation and community dynamics of meiobenthic copepods. Ecology 58: 1136-1143

Coull, B. C., Grant, J. (1981). Encystment discovered in a marine copepod. Science 212: 342-344

Coull, B. C., Hoque, E. W. (1978). Revision of Apodopsyllus (Copepoda, Harpacticoida), including two new species and a redescription. Trans. Am. microsc. Soc. 97: 149-159

Coull, B. C., Palmer, M. A. (1984). Field experimentation in meiofaunal ecology. Hydrobiologia 118: 1-19

Coull, B. C., Vernberg, W. B. (1975). Reproductive periodicity of meiobenthic copepods: seasonal or continous? Mar. Biol. 32: 289-293

Coull, B. C., Hicks, G. R. F., Wells, J. B. J. (1981). Nematode/ Copepod ratios for monitoring pollution: A rebuttal. Mar. Pollut. Bull. 12: 278-281

Coull, B. C., Bell, S. S., Savory, A. M., Dudley, B. W. (1979). Zonation of meiobenthic copepods in a southeastern U.S. salt marsh. Estuar. coast. mar. Sci. 9: 181-188

Creed, E. L., Coull, B. C. (1984). Sand dollar, Mellita quinquisperforata (Leske) and sea pansy Renilla reniformis (Cuvier) effects on meiofaunal abundance. J. exp. mar. Biol. Ecol. 84: 225-234

Eskin, R. A., Hopper, B. E. (1985). Population dynamics and description of Ptycholaimellus hibernus n. sp. (Nematoda: Chromadoridae). J. Nematol. 17: 38-45
Findlay, S. E. G. (1981). Small scale spatial distribution of meiofauna on a mud-and sandflat. Estuar. coast. Shelf Sci. 12: $471-484$

Findlay, S. E. G. (1982). Influence of sampling scale on apparent distribution of meiofauna on a sandflat. Estuaries 5: 322-324

Folk, R. L. (1968). Petrology of sedimentary rocks. Hemphills, Austin, Texas

Fry, J. C., Humphrey, N. C. B., Iles, T. C. (1981). A review, Time-series analysis for identifying cyclic components in microbiological data. J. appl. Bact. 50: 189-224

Grant, J. (1981). Factors affecting the occurrence of intertidal amphipods in reducing sediments. J. exp. mar. Biol. Ecol. 49: $203-216$

Gray, J. S., Christie, H. (1983). Predicting long-term changes in marine benthic communities. Mar. Ecol. Prog. Ser 13: $87-94$

Herman, P. M. J., Heip, C. (1983). Long-term dynamics of meiobenthic populations. Oceanologica Acta 1983: 109-112

Hogue, E. W. (1978). Spatial and temporal dynamics of a subtidal estuarine gastrotrich assemblage. Mar. Biol. 49: 211-222

Hulings, N. C., Gray, J. S. (eds.) (1971). A manual for the study of meiofauna. Smithson. Contr. Zool. 78: 1-84

Ivester, M. S. (1980). The distribution of meiobenthic copepods along a sediment gradient: Factor and niche analysis. Bull. mar. Sci. 30: 634-645

Ivester, M. S., Coull, B. C. (1977). Niche fractionation studies of two sympatric species of Enhydrosoma. Mikrofauna Meersboden 61: 131-145

de Jonge, V. N., Bouwman, L. A. (1977). A simple density separation technique for quantitative isolation of meiobenthos using the colloidal silica Ludox-TM. Mar. Biol. 42: 143-148

Kirk, B. L., Rust, B. W., Van Winkle, W. (1979). Time series analysis by the maximum entropy method. ORNL-5332, Oak Ridge National Laboratory, Oak Ridge, Tennessee

McIntyre, A. D. (1969). Ecology of marine meiobenthos. Biol. Rev. 44: 245-290

McIntyre, A. D., Murison, D. J. (1973). The meiofauna of a flatfish nursery ground. J. mar. biol. Ass. U.K. 53: 93-118

Montagna, P. A., Coull, B. E., Herring, T. L., Dudley, B. W (1983). The relationship between abundances of meiofauna and their suspected microbial food (Diatoms and Bacteria). Estuar. coast. Shelf Sci. 17: 381-394

Platt, T., Denman, K. L. (1975). Spectral analysis in ecology. Ann. Rev. Ecol. Syst. 6: 189-210

Raffaelli, D. (1981). Monitoring with meiofauna - A reply to Coull, Hicks and Wells (1981) and additional data. Mar. Pollut. Bull. 12: 381-382

Raffaelli, D. G., Mason, C. F. (1981). Pollution monitoring with meiofauna, using the ratio of nematodes to copepods. Mar. Pollut. Bull. 12: 158-163

SAS Institute Inc. (1982). SAS user's guide: statistics, 1982 ed. SAS Institute Inc., Cary, N.C.

Scheffé, H. (1959). The analysis of variance. John Wiley \& Sons, London

Sellner, B. W. (1976). Survival and metabolism of the harpacticoid copepod Thompsonula hyaenae (Thompson) fed on different diatoms. Hydrobiologia 50: 233-238

Sheridan, P. F. (1979). Trophic resource utilization by three species of Scianid fishes in a northwest Florida estuary. Northeast Gulf Sci. 3: 1-15

Sokal, R. R., Rohlf, F. J. (1981). Biometry, 2nd ed. W. H. Freeman \& Co., San Francisco

Stripp, K. (1969). Jahreszeitliche Fluktuationen von Mak- 
rofauna und Meiofauna in der Helgoländer Bucht. Veröff. Inst. Meeresforsch. Bremerhaven 12: 65-94

Tietjen, J. H. (1969). The ecology of shallow water meiobenthos in two New England estuaries. Oecologia (Berl.) 2: 251-291

Trask, P. D. (1932). Origin and environment of source sediments of petroleum. A.P.I. Gulf Publ. Co., Houston, Texas

Vernberg, W. B., Coull, B. C. (1974). Respiration of an interstitial ciliate and benthic energy relationships. Oceologia (Berl.) 16: 259-264

Vernberg, W. B., Coull, B. C. (1975). Multiple factor effects of environmental parameters on the physiology, ecology and distribution of some marine meiofauna. Cah. Biol. mar. 16: $721-732$
Vernberg, W. B., Coull, B. C. (1981). Meiofauna. In: Vernberg, F. J., Vemberg, W. B. (ed.) Functional adaptations of marine organisms, Chapter 5. Academic Press, New York, p. $147-177$

Walkley, A., Black, I. A. (1934). An examination of the Degtjareff method for determining soil organic matter, and proposed modification of the chromic titration method. Soil. Sci. 37: 29-38

Warwick, R. M. (1981). The nematode/copepod ratio and its use in pollution ecology. Mar. Pollut. Bull. 12: 329-333

Wiens, J. A. (1977). On competition and variable environments. Am. Scient. 65: 590-597

Wieser, W. (1960). Benthic studies in Buzzards Bay II. The meiofauna. Limnol. Oceanogr. 5: 121-137

This paper was presented by Professor K. R. Tenore; it was accepted for printing on April 12, 1985 